\title{
РЕЛІГІЕЗНАВСТВО
}

УДК 261.7

DOI 10.35423/2078-8142.2020.1.2.10

Г. В. Христокін, доктор філософських наук, професор кафедри філософії та політології, дочент, Університет державної фіскальної служби Украӥни м. Ірпінь, Украӥна e-mail: xristokingena@gmail.com ORCID: https://orcid.org/0000-0002-2663-3055

\section{МЕТОДОЛОГІЧНИЙ АСПЕКТ ВЗАСМОДІЇ ФІЛОСОФІЇ ТА ТЕОЛОГІї}

Актуальність дослідження взаємодії філософії та теології давно стало наскрізною проблемою гуманітарного знання. На сьогодні більшість науковиів визнають співприсутність $і$ взаємодію філософії та теології як самостійних культурних дискурсів. Не викликає особливих заперечень теза про ідейні, концептуальні взаємовпливи християнської теології та філософії, їх парадигмальний вилив на науку. У статті аналізується методологічний аспект взаємодї філософії та теології, як він постає у сучасних релігієзнавців та богословів. Доведено, що переважною більшістю православних авторів філософія мислиться в модерному ключі, як щзось зовсім окреме і незалежне від теології, а значить питання полягає в тому, щоб узгодити взаємини між ними. Натомість мислителі постмодерної парадигми сприймають філософрію $і$ теологію нерозривними, такими, що продовжують одне одного. На їхню думку, саме теологія і філософія закладають ті культурні коди, сенси i иінності, які формують матрицю культури. Теологія слугує посередником між людиною, релігією і культурою. Тому вона тісно співпрачює з філософією та іншими гуманітарними науками. Дослідження багатьох авторів ще більше актуалізує завдання аналізу методологічної складової взасмодії філософії та теології. 
Ключові слова: філософія, теологія, філософія теології, методологія теології, християнська теологія.

Теоретична рефлексія проблеми методу в теології $є$ досить рідкісна для переважної більшості християнських теологів. Якщо деякі з них і задаються питанням про власне богословську методологію, то про філософську методологію в теології мало хто говорить. У модерну добу утвердилася парадигма взаємного виключення філософії та теології. Після Фоми Аквінського нормою стала думка, що теологія базується на вірі й одкровенні, а філософія на розумі, тому між ними проведено чіткий водорозділ. Православні богослови XVIII-XIX ст. переймають це як аксіому і повсякчас намагаються продумати варіанти подолання розбіжності між філософією та теологією. Уся теологія модерної доби сповнена драматичних вирішень цієї проблеми, вагань між раціоналізмом, фідеїзмом та містицизмом. I лише в XX ст. ситуація докорінно змінюється. Постмодерна доба переводить регістр із суперечки між вірою і розумом на взаємодію рівноцінних дискурсів. Сучасні філософи не протиставляють між собою філософію та теологію, вони бачать їх як взаємно узгоджені та аналогічні дискурси. Для прикладу варто звернутися до позиції одного 3 найкращих богословів сучасності Г.У.фон Бальтазара, який доводить, що «без філософії немає богослов'я» [2, с. vii]. На його думку, будь-яке мислення в категоріях єдності буття, істини, краси та блага передбачає взаємну зумовленість і нерозривність філософії та теології. «Якщо богослов взагалі здатен бути серйозним, то він» має бути «перш за все - філософом», зазначає католицький мислитель [2, c. viii-ix]. Такий підхід долає розриви і встановлює тісні союзи між філософією та теологією.

У своїй роботі ми виходимо з тези про те, що філософські методи та підходи є невід'ємною частиною теологічного мислення [20]. Теологію не можна редукувати до коментування Писання чи моралізаторства, iї не варто ототожнювати 3 догматикою чи містикою. Теологія, за нашим переконанням, є універсальним метадискурсом, здатним, подібно до філософії, до самих широких узагальнень і світоглядних міркувань про людину, світ, культуру та їх трансцендентні й трансцендентальні передумови. Саме тому, теологія може мати самі різноманітні форми свого культурного буття [14]. 
Найбільш виразно серед православних богословів методологічну проблематику теології обговорюють О. Давидов [5], К. Говорун [4], П. Михайлов [9], С. Коначева [8], Ю. Чорноморець [18], Д. Харт [12], Г. Христокін [15]. У своїх роботах вони переконливо будують парадигмальні зв'язки між філософією та богослов'ям, показують їх нерозривність. Для них богослов'я без філософії не існує. Але, на нашу думку, поза увагою залишається методологічний аспект взаємодії теології та філософії. Увага на цей аспект дасть нам можливість найкраще продумати природу, форми та загальну перспективу спів існування філософії та теології.

Метою статті є осмислення доробку сучасних філософів, релігієзнавців та богословів на тему взаємодії філософії та теології в методологічному аспекті. Нашими завданнями стануть: короткий огляд існуючих підходів до проблеми взаємодії філософії та теології; аналіз найбільш впливових концепцій; спроба продумати перспективу подальших досліджень.

Достеменно відомо, що джерелами християнської теології були біблійна віра та антична філософія. Про роль біблійного Одкровення у формуванні християнської теології сказано чимало і ця тема не викликає особливих сумнівів [8]. Але про роль філософії у розбудові теології немає однозначного бачення в християнській традиції. У безмежності цієї проблематики спробуємо виокремити основні підходи та стратегії. Сучасний український філософ А. Баумейстер говорить про парадоксальність, внутрішній конфлікт та водночас провіденційність зустрічі античної філософії та християнства. На його думку від «початку зустрічі античності та християнства виникає внутрішнє напруження, суперечка, конфлікт. I ця ситуація внутрішнього напруження і суперечки від самого початку була заряджена могутнім творчим потенціалом, створила дуже силове поле, в якому отримали розвиток усі основні феномени нашої традиції» [3, с. 102-103].

Аналогічну позицію висловив Ю. Чорноморець, для якого «теологія є дискурсом аналогічним до філософії.. Зближує теологію 3 філософією те, що вони міркують про найбільш загальні предмети - світ, людину й Бога, виходячи 3 аксіом прийнятих без доказів. Відмінність лише в тому, що у теології аксіом більше. Разом вони претендують на статус мета-дискурсу для всіх наук; нарешті, вони ра- 
зом є специфічними науками, світоглядними дискурсами, відповідно філософським і релігійним [18].

У цьому контексті варто згадати дослідження Є. Положенкової «Співвідношення релігійної філософії і християнського богослов'я в історії релігійної думки (онтологічний і гносеологічний аспект)» (2004). Автор пише про наявність двох традицій співвідношення філософії і теології: антиномістської, яка доводить протилежність віри і знання (вона постає в раціоналістичному та містичному варіантах) і «традиції їх розуміння як єдності» [11, с. 3], що представлена у філософському ідеалізмі німецьких класиків, а також у патристиці та схоластиці. На основі цього припущення Положенкова будує стратегії («моделі», «традиції») співвідношення філософії і теології та робить їх аналіз.

Варто також згадати роботу В. С. Подоровського «Гносеологічна демаркація предмета філософії та теології» (2018). На його думку «демаркації предметів філософії та теології відповідає категоріальна опозиція ens increatum - ens creatum. «Вона надає теології вивчати тільки ті відомості про ens increatum, які мисляться як результат його самопрезентації та знайшли своє відображення в конфесійній традиції сакральної писемності» [10, с. 11]. На основі категоріальної опозиції «еns increatum - ens creatum» предмет філософії може бути представлений як ens creatum, що включає, крім всього матеріального світу, і ту частину обсягу поняття духовного світу, яка не відноситься до ens increatum» [10, с. 12]. Простими словами, критерієм демаркації теології та філософії автор вбачає принцип «створеного - нествореного». Як стверджує Подоровський, розроблені в європейській думці класичні стратегії співвідношення предмета філософії і теології, будучи продуктом онтодіцейної функції філософії, апелюють до світоглядних очікувань, викликаних змінами в конфесійних теологіях. Одночасно дані стратегії співвідношення предмета філософії і теології пов'язані з гносеологічними припущеннями певних філософських доктрин, положення яких виступають для даних стратегій в якості необхідних передумов. Прийняття цих стратегій 3 необхідністю призводить до угоди з припущеннями відповідних філософських і теологічних доктрин [10, с. 11]. 
Більш предметно проблему методології теології досліджує С. Девятова, яка, посилаючись на твори А. Пікока, Д. Полкінхорна, доводить можливість застосовувати в теології методи науки. Подібність науки і теології проявляється в тому, що теологія підкорюється загальним критеріям, «які використовує наука при дослідженні природної реальності, при аналізі й оцінці своїх моделей, гіпотез, теорій» [7]. Девятова має тут на увазі критерії раціональності (екзистенційної релевантності - збігу, співвіднесення з даними, повноти, внутрішньої логічності, несуперечливості, простоти), обгрунтованості (критерій адекватності) і плідності (продуктивності у відношенні нових ідей). Загалом, теологія і наука можуть бути амбівалентними, залежно від світоглядної позиції людини. Девятова зауважує, що «ми можемо розглядати теологію і науку, як автономні та узгоджені підходи до дійсності; різні чи подібні мовні системи; такі, що мають своїм джерелом зовсім різні чи схожі установки; такі, що володіють кожна своїм об'єктом дослідження чи такими, що описують один об'єкт - дійсність» [7, с. 276]. Зокрема, представники методології критичного реалізму вважають можливою узгоджену дію цих важливих сфер культури, в межах яких вони розглядаються як цілком сумісні і навіть дуже пов'язані підходи до дійсності. Адже, обидва вони прагнуть до осягнення сутності природи і сутності універсума, включаючи людину з їі внутрішнім світом [7, с. 276]. Отож, використовуючи моделі, метафори, концептуальні конструкції та схеми, теологія разом із наукою зможуть формувати узгоджену картину світу, визначаючи місце в ній людини.

С. Хоружий у спеціальній статті «Філософія і теологія» (19951998) пропонує альтернативне пояснення проблеми на якій варто зупинитися докладніше. Для С. Хоружого в ранньому християнстві філософія і теологія протистояли один одному як Афіни та Єрусалим, як пізнання і спілкування, як чиста думка та цілісна духовнодушевна націленість на Христа. На відміну від західного християнства, на Сході теологія ніколи не перетворювалася на суто теоретичну дисципліну, бо існувала духовна практика аскетики та відповідна ій містична мова. Усе це дає підстави Хоружому розділити у східнохристиянській (і згодом православній) традиції теоретичну теологію та містико-аскетичний дискурс, або богослов'я. Ці два дискурси тісно взаємодіючи між собою утворюють східнохристиянський дис- 
курс, але богослов'я як практичний дискурс завжди в ньому домінує.

На думку С. Хоружого, у своій побудові східнохристиянський дискурс є складним, синтетичним дискурсом, який поєднує в собі "теоретичну" мову силогістичних побудов, високо спеціалізовану, апорійну мову догмату і мову досвідного свідчення, що передає досвід богоспілкування (як містико-аскетичної практики) [13, с. 8]. При цьому і мова догмата і мова індивідуального духовного свідчення мають єдину досвідну основу, вони виражають лише два його горизонти - суб'єктивний та інтерсуб'єктивний. Тобто, досвід у східнопатристичному дискурсі, існуючи в двох вимірах - соборному та індивідуальному, має «єдину природу і єдину організацію» - так, що «перший рід досвіду є інтерсуб'єктивним розширенням і перетворенням другого» [13, с. 8].

Загалом проблема взаємодії теології та філософії у східнохристиянському дискурсі постає як питання про взаємодію трьох дискурсів: дискурсу філософії, яка ототожнюється з античною думкою, дискурсу теологіï, який наближується до філософії, копіює та використовує іï та дискурсу богослов'я як містико-аскетичної мови [13, с. 3]. Богослов'я завжди тісно пов'язане з духовною практикою i віддалене від строю і способу європейської метафізики [13, с. 7].

Як філософія - це стихія мислення й розуму, що в античній думці знаходить своє втілення в божественному мисленні, так і християнська теологія є стихією особистості Бога й спілкування 3 ним. Тому питання про відношення філософії та теології, на думку Хоружого, є питанням про взаємодію не просто теоретичного і практичного знання, не просто античної раціональної філософії та християнської теології Одкровення, і навіть не просто питанням про взаємодію цілісної античної філософії та двополярної християнської теології (теоретичної теології та богослов'я). Питання про взаємодію філософії та теології в патристиці є питанням про взаємодію двох схожих дискурсів (античного та християнського), але абсолютно різних онтологій та онтологік, і різних двох типів джерельного досвіду - досвіду мислення та досвіду спілкування. Тобто, «патристикоаскетичний дискурс постає аналогом и паралеллю дискурсу антич- 
ної філософії: відносно іншого джерельного досвіду та іншої онтологіки» [13, с. 8-9].

Як мова про досвід спілкування (у своєму суб'єктивному та інтерсуб'єктивному вимірах) теологія є рід дискурсу у високому ступені «нетермінологічному», його слова-поняття не можуть стати суто науковими, адже «їх лексико-семантичні поля наділені складною багаторівневою побудовою, включаючи чисельні асоційовані та індивідуальні сенси, конотації, референції, репертуар яких високо специфічний і не сподіваний» [13, с. 9]. Тим самим Хоружий проводить тезу про абсолютну відмінність між собою філософії та теології. На його думку, мова про досвід спілкування теології, ускладнена догматичним елементом, надзвичайно далека від мови про досвід мислення філософії. «Вони не зводимі один до одного і ніякого прямого, наглядного відношення чи відповідності між ними встановити неможна» [13, с. 9]. Тобто, на думку Хоружого, говорити про включеність богослов'я у філософію чи навпаки некоректно, бо «два дискурса відносяться до різних онтологік і різних родів буттєвого досвіду». Їх основне протистояння здійснюється на рівні досвідів мислення та спілкування, конфлікту різних онтологік, хоча у своїй повноті вони намагаються оминути його. Абсолютна відмінність філософії та богослов'я примирюється через посередництво теоретичної теології, як не-досвідного дискурсу. Вона «може будуватися в різних онтологіках і бути в різних відношеннях включення чи підлеглості як з філософією, так і з богослов'єм» [13, с. 9].

Усе сказане С. Хоружим дає можливість усвідомити відмінність між розвитком теології на християнському Сході та Заході. На Сході пануюче місце зайняло богослов'я в якому тісний зв'язок 3 аскетикою зумовив відсутність помітної ролі філософії. На Заході основне місце посіла теологія, яка, будучи віддаленою від досвіду богоспілкування, перебувала в залежності від філософських критеріїв, тому вплив філософії тут був значнішим. Теологія стала наближатися до філософського типу. Сдиним, що робило теологію християнською, був іiі зв'язок з догматом, але відмова від богослов'я зробило догмат парадоксальним і суперечливим явищем. Бо він грунтувався не на інтерсуб'єктивному досвіді богоспілкування, а став спекулятивною конструкцією, «догматичною формулою» [13, с. 10]. Врешті розрив $з$ досвідом богоспілкування породив ситуацію «роз- 
щепленого дискурсу» - розриву між теологією та богослов'ям та між філософією та теологією, а також «розщепленого досвіду», коли досвід пізнання Бога стає суто суб'єктивним і протиставляється науковому як об'єктивному. Врешті М. Гайдеггер відносить теологію до наукового типу мислення і цим протиставляє іï філософії, оформлюється протиставлення онтологічного та онтичного.

Отже, Хоружий намагається пояснити відсутність помітної ролі філософії у східній патристиці розлогою теорією про існування трьох дискурсів: богослов'я, теології та філософії у патристиці, а також непримиренним конфліктом між філософією та богослов'ям як конфліктом між досвідом мислення та досвідом спілкування. Саме для обгрунтування такого конфлікту Хоружий висуває гіпотезу про первинність досвіду як основи будь-якого дискурсу, про залежність онтології та відповідної онтологіки від базового досвіду на основі якого створюються усі теоретичні побудови філософії та християнської теології.

Як результат використання методології містичного емпіризму протиставлення між філософією та теологією переводиться в емпіричний ракурс і подається як відмінність між двома типами досвіду - мислення та спілкування. Відповідно втрачається критерій відмінності за принципом «природне - надприродне одкровення»; спрощується потрійна структура християнського дискурсу (природна теологія, надприродна теологія, містична теологія) до подвійного (надприродна теологія і містична теологія), а філософія взагалі виводиться за межі християнського мислення як здобуток античності. Тобто постулюється думка, що християнське мислення нездатне створювати філософію, що вона суперечить базовому досвіду християнства і що вона $є$ лише породженням античності. Позбавлення християнського мислення філософського компонента остаточно занурює його лише в сферу містичного і робить усі явища релігійного мислення виявами досвіду суб'єкта, Собору чи церкви.

На нашу думку недолік запропонованої Хоружим концепції полягає саме у: 1) виокремленні досвіду як єдиного джерела теоретичних побудов; використання методології містичного емпіризму для пояснення складних процесів культурного розвитку філософії та теології; 2) штучному розділенні стихії мислення та стихії спілку- 
вання як протилежних характеристик буття; відповідному протиставленні античної думки як цілісного дискурсу, що виражає стихію мислення 3 християнською думкою як роздвоєного дискурсу, що виражає стихію спілкування; 3) протиставленні філософії лише як досвіду мислення теології як лише досвіду спілкування; 4) протиставленні теології та богослов'я як теоретичної та духовнопрактичної мови в християнстві; розумінні богослов'я як мови, що виражає духовно-практичний досвід богоспілкування та теології як мови, що базується на теоретичних засадах філософії; 5) запереченні наявності філософії у структурі теології так само, як теології у структурі теології.

Недоліком більшості зазначених досліджень модерного типу $є$ бачення філософії як умогляду протилежного теології. Філософія, переважною більшістю православних авторів XIX - першої половини XX ст., мислилася як спекулятивна метафізика, відірвана від досвіду особи та церкви. Місію теології вони вбачали в подоланні філософських спекуляцій, опорі на істинну філософію - теологію. Але ситуація докорінно змінюється в некласичній філософії, яка долає метафізику, з опорою на герменевтику та феноменологію. Більшість представників філософії та християнської теології другої половини XX ст., починають мислити в постмодерній та постметафізичній парадигмі, яка знімає жорстке протиставлення віри й розуму, філософії і теології [8]. Тому розглянемо концепції деяких найбільш знакових мислителів цієї доби.

Подібний постметафізичний підхід демонструє Джон Капуто, погляди якого вплинули на формування сучасної постметафізичної теологіï. У своїй праці «Philosophy and Theology» (2006) він намагається обгрунтувати тісний союз між ними [1]. Мислитель вбачає корені конфлікту між філософією та теологією у протиставленні віри й розуму, що можна знайти в класичній опозиції Афін та Єрусалиму Туртеліана. Багато хто намагався побачити у вірі та розумі «два різних стиля життя - богословське життя віри і філософське життя розуму» [1, с. 18]. I цей конфлікт, на думку Капуто, лише посилився в епоху модернізму [1, с. 22]. Адже, якщо в Середньовіччі саме теологія була «царицею наук», то в Новий час ії місце вершини знання займають філософія і наука [1, с. 23]. Саме просвітницький «вік розуму» притягує релігію, теологію, і навіть Бога до відповідальності. 
Як наслідок, не просто філософія перестала бути служницею теології, але остання стала однією 3 дисциплін, що «контролюється вищими принципами філософії, яка слідкує за всім знанням та науками в цілому» [1, с. 43].

Насправді, зазначає Дж. Капуто, філософія і теологія нерозривні, вони 3 необхідністю вимагають і передбачають одна одну. I це зумовлене, передусім, тим, що вони разом $є$ двома різновидами віри та інтерпретації, на яких грунтуються їх концепції [1, с. 79]. Бо і філософія і теологія мають власні інтуїції, передумови, «перспективу, лексикон, яким ми віримо і довіряємо» [1, с. 78]. Так само, вони взаємно необхідні, бо допомагають оцінити одна одну. Зокрема, філософія допомагає виявити логічні, герменевтичні та методологічні помилки в теологічних судженнях та оцінити їх. Гарне володіння історією філософії та теології допоможе мислителю уникнути крайнощів фідеїзму та раціоналізму.

Цю думку продовжує американський православний богослов Д. Б. Харт. Основне завдання, яке покладає на себе Харт, - це розв’язання питання про взаємодію філософії та теології загалом як важливої проблеми, відповідь на яку має запропонувати християнство [12]. Для нього філософія і теологія не є чимось відокремленими та повністю автономними, навпаки, вони мисляться ним внутрішньо єдиними. Адже саме богослов'я, за Хартом, і породило філософію. Остання - це значною мірою «позашлюбне дитя богослов'я», своєрідний різновид «секуляризованого богослов'я». Вона народилася 3 своєрідного «краху мови віри». I тому усі пошуки та заперечення цієї віри, зумовлені «внутрішньою боротьбою християнського Заходу із самим собою» $[12$, с. 46]. Тобто, філософія для Харта є продовженням теології в інший спосіб, це самозаперечення теології, яку здійснює європейська традиція, щоб віднайти себе. Богословська проблематика буття та сущого, герменевтична інтерпретація текстів, проблема трансцендентного та іманентного, морального закону, трансценденталій, сенсу вічності та часу, долі та свободи як невід’ємні вузли європейської культурної традиції, просякають усю іiі історію аж до сучасності і $є$ варіаціями на богословську тему. Тому богослов'я $є$ первородним, виступаючи кровно спорідненим 3 філософією. І справді, ніколи філософія не існувала у відриві від теоло- 
гії, починаючи 3 часів античності. Не можна не погодитися 3 Хартом, що вся філософія і вся її проблематика, від Фалеса і до Дерріди, $\epsilon$ роздумами на богословські теми, і пошук вирішення богословських проблем. I навіть коли філософи критикували теологію, навіть коли вони створювали антирелігійні системи, вони продовжували богословські теми, перебуваючи у внутрішній дискусії з теологією. Тому філософія є різновидом теології, як і навпаки.

Отже, у статті проаналізовано методологічний аспект взаємодії філософії та теології, як він постає у сучасних релігієзнавців та богословів. Доведено, що переважною більшістю православних авторів філософія мислиться в модерному ключі, як щось зовсім окреме і незалежне від теології, а значить питання полягає в тому, щоб узгодити взаємини між ними. Натомість мислителі постмодерної парадигми сприймають філософію і теологію нерозривними, такими, що продовжують одне одного. На їхню думку, саме теологія і філософія закладають ті культурні коди, сенси і цінності, які формують матрицю культури. Теологія слугує посередником між людиною, релігією і культурою. Тому вона тісно співпрацює з філософією та іншими гуманітарними науками. Дослідження багатьох авторів ще більше актуалізує завдання аналізу методологічної складової взаємодії філософії та теології. Тому для нас у подальшому актуальним $\epsilon$ вивчення не просто питання про можливості та засоби філософського впливу на теологію. Для нас у подальших дослідженнях $\epsilon$ важливим, яким чином, у який спосіб, якими засобами філософія складає методологічну основу теології? Це становить важливу філософську проблему і предмет окремої дисципліни - філософії теології [16], адже зрозуміти сутність теологічних вчень без врахування їх методологічного підгрунтя неможливо.

\section{ЛITЕРАТУРА}

1. Caputo J. D. Philosophy and Theology. Abingdon Press, 2006. 84 c.

2. Бальтазар Г. У. Теологика. I. Истина мира / пер. 3 нем. А. Лукьянова. М. : ББИ, 2013. 301 с.

3. Баумейстер А. Афины и Иерусалим: провиденциальное единство и нескончаемая тяжба. Парадоксы деэллинизации. Біля джерел мислення $i$ буття. Вибрані філософські етюди. К. : Дух і Літера, 2012. С. 98-110. 
4. Говорун К. Риштовання Церкви: в бік постструктуральної еклезіології. К. : Дух і Літера, 2018. 312 с.

5. Давыдов О. Откровение Любви: тринитарная истина бытия. М. : ББИ, 2020. 658 с.

6. Даниелю Ж. Бог и мы / пер. с фр. Г. Смирнова; под ред. А. Мосина. Символ. 1998. № 40. С. 7-155.

7. Девятова С. В. Методология критического реализма в современной христианской теологии. URL: https://mail.google.com/mail/u/0/\#inbox?projector=1

8. Коначева С. Бог после Бога: пути постметафизического мышления. Москва : РГГУ, 2019. $242 \mathrm{c.}$

9. Михайлов П.Б. Категории богословской мысли. Москва : ПСТГУ, 2013. 310 с.

10. Подоровский В. Е. Гносеологическая демаркация предмета философии и теологии / Диссертация на соискание ученой степени кандидата философских наук. 09.00.01 Онтология и теория познания.Нац. Исслед. Ун-т им. А. Чернышевского, 2016.

11. Положенкова Е. Ю. Философия и христианское богословие: проблемы взаимосвязи / отв. ред. Т. П. Мятяш. Ростов-на-Дону : Изд-во АПСН СКНЦ ВШ, 2003. 107 с.

12. Харт Д. Красота бесконечного. Эстетика христианской истины / Девид Харт ; [пер. с англ. А. Лукьянова]. Москва : ББИ, 2010, xviii + 673 с.

13. Хоружий С. Философия и теология. О старом и новом. СПб. : Алетейя, 2000. С. 289-310.

14. Христокін Г. Культурні форми буття теології: релігієзнавчофілософський аналіз. НАУКОВИЙ ЧАСОПИС Наиіонального педагогічного університету імені М. П. Драгоманова. Серія 7. Релігієзнавство. Культурологія. Філософія : [зб. наукових праць] / ред. рада : В. П. Андрущенко (голова); за ред. Н. Г. Мозгової. Київ : Вид-во НПУ імені М. П. Драгоманова, 2017. Вип. 38 (51). С. 65-73.

15. Христокін Г. Методологія православної теології. Київ : Фоліант, 2019. $501 \mathrm{c}$.

16. Христокін Г. В. Філософія теології як галузь філософії релігії: визначення статусу дисципліни. Богословские размышления. ЕвроАзиатский журнал богословия. 2018. № 21. С. 97-107.

17. Христокін Г. Філософія як методологічна основа теології. Актуальні проблеми філософії та соціології. Науково-практичний журнал. 2016. Вип. 13. С. 81-85. 
18. Чорноморець Ю. П. Православна теологія на шляху до нової парадигми. Філософська думка-Sententiae : 2012. Спецвипуск № 3. Християнська теологія і сучасна філософія. Вінниця : ВДТУ, 2013. С. 74-88.

\section{REFERENCES}

Caputo, J. D. (2006). Philosophy and Theology. Abingdon Press. 84 s. Balthazar, G. (2013). Theology. I. The truth of the world. Moscow, 301. [In Russian].

Baumeister, A. (2012). Athens and Jerusalem: providential unity and endless litigation. De-Hellenization paradoxes. Bilya dzherel mislennya i buttya. Vibrani philosophical studies. Kyiv : Spirit and Litera, 98-110. [In Russian].

Govorun, K. (2018). Church scaffolding: towards poststructural ecclesiology. Kyiv : Dukh i Litera, 312 p. [In Ukrainia].

Davydov, O. (2020). Revelation of Love: the trinitarian truth of being. M.: ББИ. 658 p. [In Russian].

Daniel, J. (1998). God and we; lane. with fr. G. Smirnova, ed. A. Mosina. Symbol. № 40. P.7-155. [In Russian].

Konacheva, S. (2019). God after God: ways of postmetaphysical thinking. Moscow : RGGU.

Mihaylov, P. (2013). Categories of theological thought. М.: ПСТГУ.

Podorovsky,V. E. (2016). Epistemological demarcation of a subject of philosophy and theology. The Dissertation on competition of a scientific degree of the candidate of philosophical sciences. 09.00.01 Ontology and theory of knowledge. Nat. Research. Univ. A. Chernyshevsky.

Polozhenkova, E. Y. (2003). Philosophy and Christian theology: problems of interrelation. Rostov-on-Don: Izd-vo APSN SKNTS VSh.

Hart, D. (2010). The beauty of the infinite. Aesthetics of Christian Truth. M.: BBI, xviii. .

Khoruzhiy, S. (2000). Philosophy and theology. About the old and the new. SPb.: Aleteyya.

Khristokin, H. V. (2018). Filosofiya teolohiyi yak haluz' filosofiyi relihiyi: vyznachennya statusu dystsypliny. Philosophy of theology as a branch of philosophy of religion: determining the status of the discipline. Yevro-Aziat $\cdot \mathrm{s}^{\prime} \mathrm{kyy}$ 
zhurnal bohoslov'ya, № 21, 97-107.

Khristokin, G. (2017). Cultural forms of existence of theology: religious and philosophical analysis. SCIENTIFIC JOURNAL of the National Pedagogical University named after MP Drahomanov. Series 7. Religious Studies. Culturology. Philosophy: [col. scientific works]. Kyiv: MP Drahomanov National Pedagogical University Publishing House. Issue. 38 (51), p.65-73.

Khristokin, G., (2019). Methodology of Orthodox Theology. Kyiv: Foliant. 501 p.

Khristokin, G. (2016). Philosophy as a methodological basis of theology. Current issues of philosophy and sociology. Scientific and practical journal. Issue. 13. P. 81-85.

Chornomorets, Y. (2013). Orthodox theology on the way to a new paradigm. Philosophical thought. Sententiae: special issue. № 3 Christian theology and modern philosophy. Vinnytsia: VSTU. P. 74-88.

\title{
Hennadii Khrystokin
}

Doctor of Philosophical Sciences, Professor of the Department of Philosophy and Political Science, Director of the Educational-Scientific Institute of Humanities, University of the State Fiscal Service of of Ukraine; Irpin, Ukraine; e-mail: xristokingena@gmail.com; ORCID: https://orcid.org/00000002-2663-3055

\section{Methodological aspect of interaction of philosophy and theology}

\begin{abstract}
s
The relevance of the study of the interaction of philosophy and theology has long been a cross-cutting problem of humanities knowledge. Today, most scholars recognize the coexistence and interaction of philosophy on theology as independent cultural discourses. The thesis about ideological, conceptual mutual influences of Christian theology and philosophy, their paradigmatic influence on science does not cause special objections. The article analyzes the methodological aspect of the interaction of philosophy and theology, as it appears in modern theologians and theologians. It is proved that the vast majority of Orthodox authors think of philosophy in a modern way, as
\end{abstract}


something completely separate and independent of theology, so the question is to reconcile the relationship between them. Instead, thinkers of the postmodern paradigm perceive philosophy and theology as inseparable, as continuing each other. In their view, it is theology and philosophy that lay down the cultural codes, meanings and values that form the matrix of culture. Theology mediates between man, religion and culture. Therefore, it works closely with philosophy and other humanities. The research of many authors further actualizes the task of analyzing the methodological component of the interaction of philosophy and theology.

Keywords: philosophy, theology, philosophy of theology, methodology of theology, Christian theology. 